University of New Hampshire

University of New Hampshire Scholars' Repository

4-15-2014

\title{
Brown carbon in the continental troposphere
}

Jiumeng Liu

Georgia Institute of Technology

Eric Scheuer

University of New Hampshire - Main Campus, Eric.Scheuer@unh.edu

Jack E. Dibb

University of New Hampshire, jack.dibb@unh.edu

Luke D. Ziemba

NASA

Kenn L. Thornhill

NASA

See next page for additional authors

Follow this and additional works at: https://scholars.unh.edu/earthsci_facpub

Part of the Atmospheric Sciences Commons

\section{Recommended Citation}

Liu, J., et al. (2014), Brown carbon in the continental troposphere, Geophys. Res. Lett., 41, 2191-2195, doi:10.1002/ 2013GL058976.

This Article is brought to you for free and open access by the Earth Sciences at University of New Hampshire Scholars' Repository. It has been accepted for inclusion in Earth Sciences Scholarship by an authorized administrator of University of New Hampshire Scholars' Repository. For more information, please contact Scholarly.Communication@unh.edu. 


\section{Authors}

Jiumeng Liu, Eric Scheuer, Jack E. Dibb, Luke D. Ziemba, Kenn L. Thornhill, Bruce Anderson, Armin Wisthaler, Tomas Mikoviny, J J. Devi, Mike Bergin, and Rodney J. Weber 


\section{Geophysical Research Letters}

\section{RESEARCH LETTER}

10.1002/2013GL058976

Key Points:

- $\mathrm{BrC}$ is prevalent in the troposphere and increases relative to $B C$ with altitude

- Optical closure is obtained between $\mathrm{BrC}$ plus $\mathrm{BC}$ and total absorption at $365 \mathrm{~nm}$

- BrC contributes $20 \%$ to top of atmosphere absorbing aerosol forcing

Supporting Information:

- Readme

- Table S1

- Table S2

- Figure S1

- Figure S2

Correspondence to:

R. Weber,

rodney.weber@eas.gatech.edu

\section{Citation:}

Liu, J., et al. (2014), Brown carbon in the continental troposphere, Geophys. Res. Lett., 41, 2191-2195, doi:10.1002/ 2013GL058976.

Received 7 DEC 2013 Accepted 12 FEB 2014 Accepted article online 15 FEB 2014 Published online 20 MAR 2014

\section{Brown carbon in the continental troposphere}

\author{
Jiumeng Liu ${ }^{1,2}$, Eric Scheuer ${ }^{3}$, Jack Dibb ${ }^{3}$, Luke D. Ziemba ${ }^{4}$, Kenneth. L. Thornhill ${ }^{4}$, Bruce E. Anderson ${ }^{4}$, \\ Armin Wisthaler ${ }^{5}$, Tomas Mikoviny ${ }^{6}$, J Jai Devi ${ }^{7}$, Michael Bergin ${ }^{7}$, and Rodney J. Weber ${ }^{1}$ \\ ${ }^{1}$ School of Earth and Atmospheric Sciences, Georgia Institute of Technology, Atlanta, Georgia, USA, ${ }^{2}$ Now at Atmospheric \\ Sciences and Global Change Division, Pacific Northwest National Laboratory, Richland, Washington, USA, ${ }^{3}$ Institute for the \\ Study of Earth, Oceans, and Space, University of New Hampshire, Durham, New Hampshire, USA, ${ }^{4}$ NASA Langley Research \\ Center, Hampton, Virginia, USA, Institut fuer Ionenphysik und Angewandte Physik, Innsbruck, Austria, ${ }^{6}$ Oak Ridge \\ Associated Universities (ORAU), Oak Ridge, Tennessee, USA, ${ }^{7}$ School of Civil and Environmental Engineering, Georgia \\ Institute of Technology, Atlanta, Georgia, USA
}

\section{Introduction}

Aerosol components that absorb light affect the planetary radiation budget directly and through secondary effects. Black carbon (BC), the strongest absorbing component of atmospheric aerosols, substantially warms the climate [Bond et al., 2013]. Recent studies have shown that organic matter, which was generally only thought to scatter light, can also contribute to light absorption. This so-called brown carbon $(\mathrm{BrC})$ derives its name from enhanced light absorption at shorter wavelengths by organic chromophores [Andreae and Gelencser, 2006].

$\mathrm{BrC}$ has both primary and secondary sources. Primary $\mathrm{BrC}$ is emitted from incomplete combustion. Secondary organic aerosol (SOA) from these combustion sources can also produce BrC [Zhang et al., 2013; Saleh et al., 2013], as can SOA from biogenic organic compounds [Zhang et al., 2013; Limbeck et al., 2003].

Ambient surface-based measurements show that $\mathrm{BrC}$ is ubiquitous. Throughout Europe, $\mathrm{BrC}$ has been linked with biomass burning and HULIS [Lukacs et al., 2007]. In the southeastern U.S., BrC has been found in rainwater from continental sources [Kieber et al., 2006] and fine particles associated with biomass burning in winter and possibly secondary aerosols in summer [Hecobian et al., 2010]. Chemical analysis has identified specific nitro-aromatic chromophores [Desyaterik et al., 2013; Zhang et al., 2013; Mohr et al., 2013], but most chromophores remain unidentified. These studies involved highly sensitive spectrophotometric measurements of $\mathrm{BrC}$ in liquid samples, either from filter extracts or online instruments [Hecobian et al., 2010], and have clearly demonstrated that $\mathrm{BrC}$ exists. In contrast, optical instruments have had difficulty unambiguously distinguishing brown from black carbon. Although able to detect $\mathrm{BrC}$ with high sensitivity in liquids, these spectrophotometric methods have limitations when used to address BrC's optical importance. Liu et al. [2013] used size resolved measurements of light absorption of solutions at surface sites to estimate particle light absorption $\left(b_{a p}\right)$ by $\mathrm{BrC}$, under a range of assumptions. Here, this work is extended to aircraftbased filter measurements, which are used to map the extent of $\mathrm{BrC}$ throughout the continental free troposphere relative to $B C$ and perform an optical closure analysis to assess the contribution of $B r C$ to an overall observed light absorption coefficient. A radiative transfer model, based on measured aerosol optical properties, is then used to assess the contributions of $\mathrm{BrC}$ to direct aerosol radiative forcing relative to $\mathrm{BC}$. 


\section{Methods}

\subsection{Aircraft Sample Collection}

Integrated filter samples of particles with aerodynamic diameters nominally smaller than $4.1 \mu \mathrm{m}$ [McNaughton et al., 2007] were collected during the National Science Foundation DC3 campaign conducted in May and June 2012. The study area focused on central USA with the NASA DC-8 research aircraft based out of Salina, KS. Supporting information Figure S1 shows a map of flight paths and filter-sampling frequency at different altitudes. Filter samples (Teflon EMD Millipore, $1 \mu \mathrm{m}$ pore size, $90 \mathrm{~mm}$ diameter) were generally collected during level flight legs over typically $5 \mathrm{~min}$ integration times.

\subsection{Brown Carbon Measurements}

Filters were stored below freezing in the dark, until extracted. This involved a first extraction in high-purity water via $30 \mathrm{~min}$ of sonication. The extracts were then filtered through a $25 \mathrm{~mm}$ diameter $0.45 \mu \mathrm{m}$ pore syringe filter (Fisher Scientific, Fisherbrand* Syringe Filters). Water extracts were transferred into a $2.5 \mathrm{~m}$ long liquid waveguide capillary cell (World Precision Instruments) followed by a Total Organic Carbon Analyzer to determine the watersoluble light absorption spectra and water-soluble organic carbon mass, following the method by Hecobian et al. [2010]. The spectrophotometer employed a UV-Vis light source (200 to $900 \mathrm{~nm}$ wavelength range) and light absorption detector (Ocean Optics) that provided highly spectrally resolved absorption data over a wide wavelength range. Light absorption of the soluble aerosol components was determined from the difference relative to the pure solvent. The same filter was then drip dried and extracted in methanol (VWR International, A. C.S. Grade,) and the light absorption of the extract was again measured. The sum of the water and methanol light absorption is taken as the "total" solution absorption (Total_Abs $(\lambda)$ ) with an estimated measurement uncertainty of $\sim 34 \%$ (see supporting information for more details on uncertainties), and it is assumed that these solvents largely extract all the $\mathrm{BrC}$ [Chen and Bond, 2010]. Here we do not discuss the fraction of water and methanolextracted $\mathrm{BrC}$, focusing only on the total absorption by $\mathrm{BrC}$, as defined by this method.

Particle light absorption at all measured wavelengths was estimated from the solution data by doubling the absorption coefficient measured from the liquid samples. This factor is based on size-distribution measurements of $\mathrm{BrC}$ in extracts made at both rural and urban sites and Mie theory calculations [Liu et al., 2013]. A factor of 2 accounts for most chromophores being in a highly effective light absorption size range (geometric mean diameter of $0.5 \mu \mathrm{m}$ ) and assuming that the $\mathrm{BrC}$ is externally mixed with other light absorbers. In contrast to a factor of 2 , a factor of approximately 0.7 has been used if the $\mathrm{BrC}$ is assumed to be associated with much smaller particles [Sun et al., 2007]. Estimates of the light absorption coefficient by aerosol $\mathrm{BrC}$ at a given wavelength $\lambda$ are denoted as $b_{a p, \operatorname{BrC}}(\lambda)$.

\subsection{Online Determination of Aerosol Light Absorption}

A Particle Soot Absorption Photometer (PSAP) measured particle light absorption coefficients at three different wavelengths: 470,532, and $660 \mathrm{~nm}$ (denoted as $b_{a p \text {,PSAP }}(\lambda)$ ) for aerosols below $4.1 \mu \mathrm{m}$ aerodynamic diameter. PSAP data were corrected for known artifacts associated with filter-based optical absorption measurements [Virkkula, 2010]. The correction has an estimated uncertainty of $0.2 \mathrm{Mm}^{-1}$ or $20 \%$, whichever is larger. Additionally, BC mass concentrations were determined with a SP2 (Single Particle Soot Photometer). The PSAP absorption coefficient at $660 \mathrm{~nm}\left(b_{a p, P S A P}(660)\right)$ and the SP2 BC concentrations were highly correlated $\left(r^{2}=0.86\right)$. Online data were averaged to the filter-sampling times when the data covered greater than $75 \%$ of the filter integration time.

Light absorption as a function of wavelength tends to follow a power law, $b_{a p} \sim \lambda^{-\mathrm{AAE}}$, where AAE is the Absorption Ångström Exponent. The ambient aerosol AAE can be determined from the multi-wavelength PSAP data and then used to estimate aerosol absorption at other wavelengths. Here the AAE was calculated from the wavelength pair 470 and $660 \mathrm{~nm}$ and then used to estimate the aerosol absorption at $365 \mathrm{~nm}$, using equations (1) and (2), respectively.

$$
\begin{gathered}
\mathrm{AAE}_{\mathrm{PSAP}}=-\frac{\ln \left(b_{a p, \mathrm{PSAP}}(660)\right)-\ln \left(b_{a p, \mathrm{PSAP}}(470)\right)}{\ln (660)-\ln (470)} \\
b_{a p, \mathrm{PSAP}}(365)=b_{a p, \mathrm{PSAP}}(660) \cdot\left(\frac{365}{660}\right)^{-\mathrm{AAE}_{\mathrm{PSAP}}}
\end{gathered}
$$




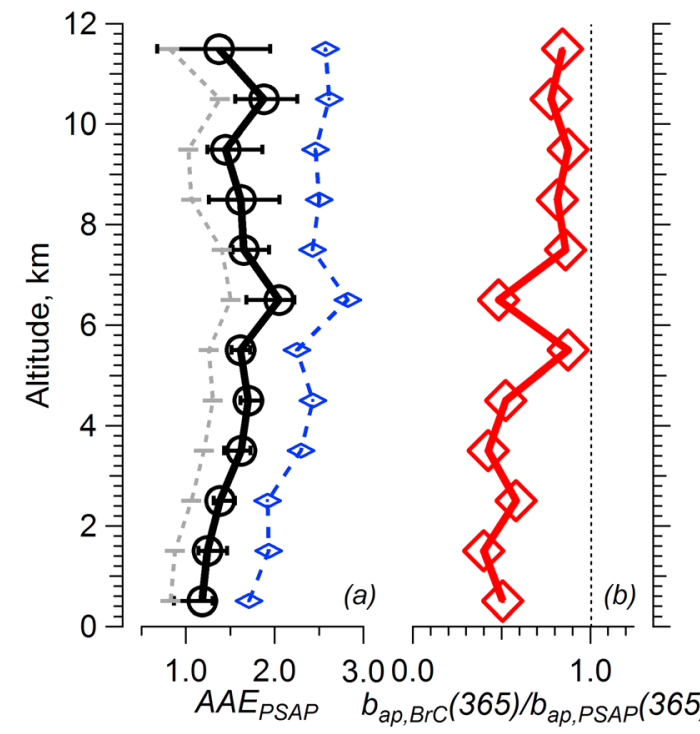

Figure 1. Vertical profiles of (a) Absorption Ångström Exponent retrieved from Particle Soot Absorption $660 \mathrm{~nm}$ (black circles), 470 and $532 \mathrm{~nm}$ (blue diamonds), and 532 and $660 \mathrm{~nm}$ (grey bars) (the $470-660 \mathrm{~nm}$ pair is used in all calculations) and (b) the ratio of brown carbon $(\mathrm{BrC})$ to total observed absorption (i.e., PSAP data) light absorption coefficients at $365 \mathrm{~nm}$. Data shown in the figure represent medians of the calculated values in each $1 \mathrm{~km}$ altitude bin, while error bars indicate the inter-quartile range. Photometer (PSAP) absorption with wavelength pairs 470 and

Different pairs (i.e., $470-532 \mathrm{~nm}, 532-660 \mathrm{~nm}$ ) result in systematic differences of approximately $20 \%$ in $b_{a p, \mathrm{PSAP}}(365)$ (see Figure 1). We arbitrarily use light absorption coefficients at $365 \mathrm{~nm}$ since this is a wavelength where $\mathrm{BrC}$ absorption is significant and is consistent with past studies. For each filter measurement, the AAE was calculated from the average of the PSAP data over the filtersampling interval.

Since data on light absorption by only $B C$ is not available, the $\mathrm{BC}$ absorption at $365 \mathrm{~nm}\left(b_{a p}, \mathrm{BC}(365)\right)$ was calculated from light absorption coefficients recorded at longer wavelengths (PASP at $660 \mathrm{~nm}$ ), where contributions from $\mathrm{BrC}$ should be minimal (discussed below). $\mathrm{BC}$ light absorption at shorter wavelengths is then estimated using an assumed $B C A A E\left(A A E_{B C}\right)$ by

$$
b_{a p, \mathrm{BC}}(365)=b_{a p, \mathrm{PSAP}}(660) \cdot\left(\frac{365}{660}\right)^{-\mathrm{AAE}_{\mathrm{BC}}}
$$

We use an $A A E_{B C}$ of 1 [Bergstrom et al., 2002; Schnaiter et al., 2005; Kirchstetter et al., 2004], but values in the range of 0.85 to 1 have also been employed by other investigators [Feng et al., 2013; Kirchstetter and Thatcher, 2012].

\section{Results}

3.1. Identification of Biomass Burning Plumes

In this analysis, the focus was on typical remote atmospheric conditions. Since during the DC3 campaign, some aircraft flights were targeted specifically to investigate biomass-burning emissions, possible bias from periodic large contributions from biomass burning was removed from the data set. Biomass burning plumes were identified by $\mathrm{CO}$ and acetonitrile $\left(\mathrm{CH}_{3} \mathrm{CN}\right)$ enhancements. If the coefficient of determination $\left(r^{2}\right)$ between $\mathrm{CO}$ and $\mathrm{CH}_{3} \mathrm{CN}$ was higher than 0.5 during the period of enhanced $\mathrm{CO}$, the plume was designated as biomass burning [de Gouw et al., 2004]. Roughly $12 \%$ of the 615 collected filters were removed from the mission data set by this criterion (supporting information Table S2).

\subsection{Vertical Profiles}

Spectrophotometric measurements of aerosol solution extracts directly measure the spectral characteristics of BrC. Supporting information Figure S2 shows the light absorption spectra of the solution extract from one filter. The observed spectra demonstrate the optical characteristics of BrC: relatively high absorption at shorter wavelengths compared to longer wavelengths (e.g., $500 \mathrm{~nm}$ ). AAE for $\mathrm{BrC}$ was determined from the linear regression fit of extract solution $\log (A b s)$ versus $\log (\lambda)$ in wavelength range $300-450 \mathrm{~nm}$ (see supporting information Figure S2) and assuming that the same AAE applies to estimates of absorption by BrC aerosols. When binned into $1 \mathrm{~km}$ intervals and then averaged, the BrC AAE was found to be fairly constant with altitude, ranging from 4.1 to 6.4, suggesting some degree of uniformity in $\mathrm{BrC}$ optical characteristics throughout the column.

In contrast, the ambient aerosol AAE (i.e., $A A E_{P S A P}$ ) for this study was $1.60 \pm 0.61$. When binned and averaged in $1 \mathrm{~km}$ altitude intervals, the AAE greater than 1 could be due to the contribution of $\mathrm{BrC}$, but based on these types of measurements alone, it is difficult to ascertain given the measurement uncertainties variability in AAEs that are possible from different sources and possible influence of particle morphology [Lack and Langridge, 2013] on observed AAE. In this case, however, we have a direct measurement of $\mathrm{BrC}$. Figure $1 \mathrm{~b}$ shows an estimate of the relative contribution of $\mathrm{BrC}$ to total aerosol absorption at a wavelength of $365 \mathrm{~nm}\left(b_{a p, \mathrm{BrC}}(365) / b_{a p, \mathrm{PSAP}}(365)\right)$ versus altitude; the fraction of $\mathrm{BrC}$ tends to increase relative to total absorption with increasing altitude, broadly consistent with the observed AAE $E_{\text {PAP }}$ vertical trend. 


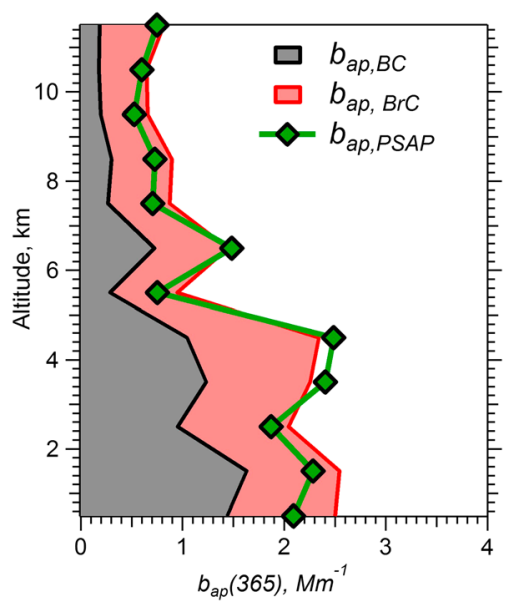

Figure 2. Vertical profiles of estimated black carbon (BC) and $\mathrm{BrC}$ absorption coefficients, along with the inferred ambient aerosol observed total absorption (PSAP), all at $365 \mathrm{~nm}$. Uncertainty associate with each parameter was $45 \%$ for $b_{a p, \mathrm{BrC}}(365), 22 \%$ for $b_{a p, \mathrm{BC}}(365)$, and $29 \%$ for $b_{a p, \mathrm{PSAP}}(365)$ (details in supporting information).

These observations appear to result from $\mathrm{BrC}$ being more evenly distributed throughout the tropospheric column than BC. The altitude at which the column-integrated absorption is half of the absorption in the total column is $3.7 \mathrm{~km}$ for BC (i.e., $b_{a p, \mathrm{PSAP}}(660)$ ), compared to $5.5 \mathrm{~km}$ for $\mathrm{BrnC}$ at $365 \mathrm{~nm}\left(b_{a p, \mathrm{BrC}}(365)\right)$. This variability in $\mathrm{BC}$ and $\mathrm{BrC}$ with altitude can also be seen in Figure 2, where the vertical profile of the $1 \mathrm{~km}$ binned median absorption coefficient at $365 \mathrm{~nm}$ is plotted for $\mathrm{BC}, \mathrm{BrC}$, and ambient absorption coefficient inferred from the PSAP measurements. Light absorption for all components is highest at the lower altitudes; however, $\mathrm{BrC}$ relative to $B C$ is greater at higher altitudes. Given that $B C$ is a primary pollutant emitted mainly at the surface (i.e., ignoring aircraft emissions), whereas $\mathrm{BrC}$ can be both primary and secondary, it seems likely that relatively greater prevalence at higher altitudes reflects at least some contribution by in situ production of $\mathrm{BrC}$.

\subsection{Optical Closure}

An optical closure analysis can be used to test the consistency of absorption delineated into $\mathrm{BC}$ and $\mathrm{BrC}$ relative to the total observed aerosol light absorption. The sum of $\mathrm{BC}$ and $\mathrm{BrC}$ should equal the total observed absorption at a given wavelength. Figure 2 shows that the $\mathrm{BC}$ absorption coefficient at $365 \mathrm{~nm}$ is always less than the total absorption estimated from the PSAP data, based on the inferred AAE. The $\mathrm{BrC}$ absorption tends to fill the difference between these curves and suggests some degree of closure. A more quantitative closure test is shown in Figure 3, where the orthogonal distance regression is calculated for just BC versus PSAP absorption coefficients at $365 \mathrm{~nm}$, in contrast to the sum of the estimated $\mathrm{BC}$ plus $\mathrm{BrC}$ versus PSAP absorption. For this study, based on the slopes, at $365 \mathrm{~nm}, \mathrm{BC}$ accounted for roughly $75 \%$ of the total absorption, adding $\mathrm{BrC}$ resulted in a slope near 1. Using the small particle limit for conversion of solvent-extract absorption to ambient particle absorption (multiplication factor of 0.7 instead of 2), the slope would be 0.82 for $B C+B r C$ versus

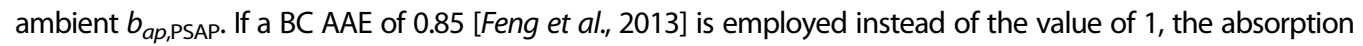
coefficients for $\mathrm{BC}+\mathrm{BrC}$ versus PSAP would still be close to 1 , but with a smaller intercept $\left(0.27 \mathrm{Mm}^{-1}\right)$. Precise values for many of these variables are not known, and there are uncertainties associated with the various measurements and calculations (see supporting information). More closure experiments are required to better assess this approach in a range of environments; however, the direct measurements of $\mathrm{BrC}$ demonstrate its prevalence, and these comparisons suggest that it is optically important at short wavelengths.

\subsection{Radiative Forcing}

The vertically resolved wavelength-dependent light absorption coefficients for $\mathrm{BC}$ and $\mathrm{BrC}$, along with measurements of the light scattering coefficients (see details in supporting information), can be used to estimate the top of atmosphere (TOA) direct radiative forcing for the total aerosol population, as well as the contribution from BrC. Vertically resolved optical properties were used to calculate the clear-sky shortwave
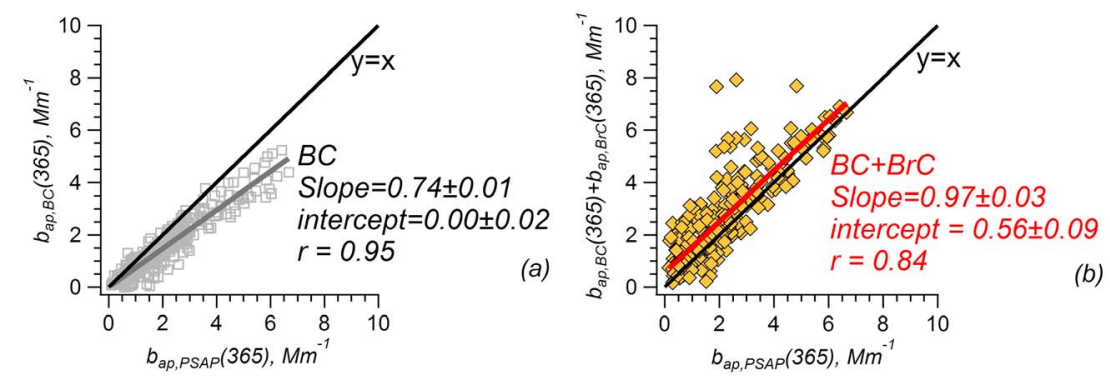

Figure 3. Closure analysis of absorption coefficients at $365 \mathrm{~nm}$ between (a) $B C$ and (b) the sum of $B C$ and $B r C$, each compared to total aerosol absorption from PSAP data. Orthogonal distance regression fit results are shown. 
( 0.25 to $4 \mu \mathrm{m}$ ) radiative forcing at the top of the atmosphere and at the surface using the Santa Barbara DISORT Atmospheric Radiative Transfer (SBDART model). Altitude-dependent single scattering albedo (SSA), aerosol optical depth (AOD), and asymmetry parameter $(g$ ) were used as inputs to SBDART. SSA and AODs were calculated from the aircraft measurements and a uniform $g$-value of 0.65 [Carrico et al., 2003] was used across all wavelengths. Surface albedo for vegetation and atmospheric profile for a standard midlatitude summer were assumed. Two sets of runs were made, one assuming absorption only from $\mathrm{BC}\left(b_{a p, \mathrm{BC}}\right)$ and another assuming that absorption is attributed to both black and brown carbon $\left(b_{a p, \mathrm{BC}}+b_{a p, \mathrm{BrC}}\right)$.

Instantaneous total downward and upward fluxes were calculated at both the top of the atmosphere and at the surface for a solar zenith angle of $40^{\circ}$, which is comparable to both mean and median solar zenith angles during the measurement period. The instantaneous forcings at TOA were -19.3 and $-24.8 \mathrm{Wm}^{-2}$ for $\mathrm{BC}+\mathrm{BrC}$ and $\mathrm{BC}$, respectively. The overall negative forcing is due to cooling by aerosol scattering; however, when $\mathrm{BrC}$ absorption is included, the net cooling is appreciably less. Similarly, instantaneous forcings at the surface were -51.0 and $-43.1 \mathrm{Wm}^{-2}$ for $\mathrm{BC}+\mathrm{BrC}$ and $\mathrm{BC}$, respectively. These values indicate that the $\mathrm{BrC}$ accounted for approximately $20 \%$ of the overall aerosol absorption contribution to radiative forcing. Or in other words, for the aerosol loadings recorded in the continental US troposphere during this limited study, $\mathrm{BrC}$ increased the shortwave solar absorption in the atmosphere by roughly $20 \%$ over what would occur if it were not present, demonstrating its importance as a climate forcing agent.

\section{Acknowledgments}

This project was funded by GIT NASA contracts NNX12AB83G and NNX08AH80G, EPA STAR grant R83503901, and UNH NASA contract NNX12AB80G. We thank Joshua Schwarz and Ru-shan Gao from NOAA, and Glenn Diskin from NASA, for data support.

The Editor thanks two anonymous reviewers for their assistance in evaluating this paper.

\section{References}

Andreae, M., and A. Gelencser (2006), Black carbon or brown carbon? The nature of light-absorbing carbonaceous aerosols, Atmos. Chem. Phys., 6, 3131-3148.

Bergstrom, R. W., P. B. Russell, and P. B. Hignett (2002), The wave- length dependence of black carbon particles: Predictions and results from the TARFOX experiment and implications for the aerosol single scattering albedo, J. Atmos. Sci., 59, 567-577.

Bond, T. C., et al. (2013), Bounding the role of black carbon in the climate system: A scientific assessment, J. Geophys. Res. Atmos., 118, 5380-5552, doi:10.1002/jgrd.50171.

Carrico, C. M., M. H. Bergin, J. Xu, K. Baumann, and H. Maring (2003), Urban aerosol radiative properties: Measurements during the 1999 Atlanta Supersite Experiment, J. Geophys. Res., 108(D7), 8422, doi:10.1029/2001JD001222.

Chen, Y., and T. C. Bond (2010), Light absorption by organic carbon from wood combustion, Atmos. Chem. Phys., 10, 1773-1787.

de Gouw, J. A., et al. (2004), Chemical composition of air masses transported from Asia to the U.S. West Coast during ITCT 2K2: Fossil fuel combustion versus biomass burning signatures, J. Geophys. Res., 109, D23S20, doi:10.1029/2003JD004202.

Desyaterik, Y., Y. Sun, X. Shen, T. Lee, X. Wang, T. Wang, and J. L. Collett Jr. (2013), Speciation of "brown" carbon in cloud water impacted by agricultural biomass burning in eastern China, J. Geophys. Res. Atmos., 118, 7389-7399, doi:10.1002/jgrd.50561.

Feng, Y., V. Ramanathan, and V. R. Kotamarthi (2013), Brown carbon: A significant atmospheric absorber of solar radiation?, Atmos. Chem. Phys. Discuss., 13, 2795-2833.

Hecobian, A., X. Zhang, M. Zheng, N. Frank, E. S. Edgerton, and R. J. Weber (2010), Water-soluble organic aerosol material and the lightabsorption characteristics of aqueous extracts measured over the southeastern United States, Atmos. Chem. Phys., 10, 5965-5977.

Kieber, R. J., R. F. Whitehead, S. N. Reid, J. D. Willey, and P. J. Seaton (2006), Chromophoric dissolved organic matter (CDOM) in rainwater, southeastern North Carolina, USA, J. Atmos. Chem., 54, 21-41.

Kirchstetter, T. W., and T. L. Thatcher (2012), Contribution of organic carbon to wood smoke particulate matter absorption of solar radiation, Atmos. Chem. Phys. Discuss., 12, 5803-5816.

Kirchstetter, T. W., T. Novakov, and P. V. Hobbs (2004), Evidence that the spectral dependence of light absorption by aerosols is affected by organic carbon, J. Geophys. Res., 109, D21208, doi:10.1029/2004JD004999.

Lack, D. A., and J. M. Langridge (2013), On the attribution of black and brown carbon light absorption using the Ångström exponent, Atmos. Chem. Phys. Discuss., 13, 15,493-15,515.

Limbeck, A., M. Kulmala, and H. Puxbaum (2003), Secondary organic aerosol formation in the atmosphere via heterogeneous reaction of gaseous isoprene on acidic particles, Geophys. Res. Lett., 30(19), 1996, doi:10.1029/2003GL017738.

Liu, J., M. Bergin, H. Guo, L. King, N. Kotra, E. Edgerton, and R. J. Weber (2013), Size-resolved measurements of brown carbon and estimates of their contribution to ambient fine particle light absorption based on water and methanol extracts, Atmos. Chem. Phys. Discuss., 13, 18,233-18,276, doi:10.5194/acpd-13-18233-2013.

Lukacs, H., et al. (2007), Seasonal trends and possible sources of brown carbon based on 2-year aerosol measurements at six sites in Europe J. Geophys. Res., 112, D23S18, doi:10.1029/2006JD008151.

McNaughton, C., et al. (2007), Results from the DC-8 inlet characterization experiment (DICE): Airborne versus surface sampling of mineral dust and sea salt aerosols, Aerosol Sci. Technol., 41, 136-159.

Mohr, C., et al. (2013), Contribution of nitrated phenols to wood burning brown carbon light absorption in Detling, United Kingdom during winter time, Environ. Sci. Technol., 47(12), 6316-6324, doi:10.1021/es400683v.

Saleh, R., C. J. Hennigan, G. R. McMeeking, W. K. Chuang, E. S. Robinson, H. Coe, N. M. Donahue, and A. L. Robinson (2013), Absorptivity of brown carbon in fresh and photo-chemically aged biomass-burning emissions, Atmos. Chem. Phys., 13, 7683-7693.

Schnaiter, M., et al. (2005), Measurement of wavelength resolved light absorption by aerosols utilizing a UV-VIS extinc- tion cell, Aerosol Sci. Technol., 39, 249-260.

Sun, H. L., L. Biedermann, and T. C. Bond (2007), Color of brown carbon: A model for ultraviolet and visible light absorption by organic carbon aerosol, Geophys. Res. Lett., 34, L17813, doi:10.1029/2007GL029797.

Virkkula, A. (2010), Correction of the calibration of the 3-wavelength particle soot absorption photometer (3 PSAP), Aerosol Sci. Technol., 44, 706-712.

Zhang, X., Y.-H. Lin, J. D. Surratt, and R. J. Weber (2013), Sources, composition and absorption angström exponent of light-absorbing organic components in aerosol extracts from the Los Angeles Basin, Environ. Sci. Technol., 47(8), 3685-3693. 